\title{
Tieto on ValtaA \\ - MYÖS SOSIAALITIETEISSÄ
}

Pääkirjoitus

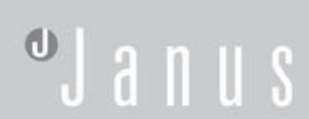

Vuosi 2018 on tutkimustiedon saatavuuden ja saavutettavuuden merkkivuosi Sosiaalityön tutkimuksen seuralle. Taustalla on ensinnäkin kumppanuusseuramme Sosiaalipoliittisen yhdistyksen kanssa julkaisemamme Janus-lehden siirtyminen Open Access -julkaisumuotoon. Tästä myös Sosiaalipoliittisen yhdistyksen puheenjohtaja, professori ja varadekaani Liisa Häikiö kirjoitti Januksen kuluvan vuoden ensimmäisessä numerossa.

Tieteellisessä julkaisutoiminnassa on vahvistunut vaatimus tieteellisen tiedon saatavuudesta ja saavutettavuudesta siten, että tutkimus on vapaasti luettavissa internetissä välittömästi tutkimuksen julkaisun jälkeen. Tavoitteena on, että tutkimukset julkaistaan kokotekstinä ilman, että niiden käyttöön tai levitykseen kohdistuisi rajoituksia. Janus on ottanut tässä asiassa tärkeän harppauksen eturintamassa suomalaisten tiedelehtien joukossa. Sosiaalityön tutkimuksen seura on toimintasuunnitelmassaan asettanut tavoitteekseen muun muassa "parantaa sosiaalityön tutkimuksen asemaa yhteiskunnassa, edistää tutkimustulosten, asiantuntemuksen ja kokemusten vaihtoa eri toimijoiden välillä”. Tähän tavoitteeseen toteutettu muutos vastaa erinomaisesti.

Sosiaalityö on hyvä esimerkki laaja-alaisesta yhteiskuntatieteellisestä asiantuntijatyöstä, josta sijoitutaan käytännön työelämässä erilaisiin sosiaalityön asiakas-, hallinto-, tutkimus-, kehittämis- ja opetustehtäviin sekä muihin vaativiin asiantuntijatehtäviin. Tietoa tarvitaan oman osaamisen ja asiantuntijuuden rakentamisessa; asiantuntijuus kasvaa teoreettisen tiedon, ammatillisen osaamisen ja tutkimuksellisten taitojen vuoropuheluna. Suhde tietoon saattaa kuitenkin muuttua siirryttäessä hektiseen työelämään. Kun kalenterin täyttävät asiakastapaamiset, palaverit, päätöksenteko ja muut arjen vastuut, voi tutkimuksen maailmaan uppoutuminen ja työn kehittäminen tätä tietoa hyödyntämällä olla vaikeaa. Esimerkiksi tarkastellessamme vielä julkaisemattomassa tutkimuksessamme (Kuusisto \& Kalliomaa-Puha) sosiaalihuoltolain (1301/2014) tarjoamien uusien välineiden käyttöönottoa kuntien sosiaalityössä erityistä tukea tarvitsevien asiakkaiden, tässä tapauksessa päihdeongelmaisten asiakkaiden kohdalla, tulokset olivat jopa hälyttäviä.Vain kolme neljästä sosiaalityöntekijästä oli päässyt osallistumaan lakia koskevaan koulutukseen. Sosiaalityön asiakastyötä tekevistä vastaajista vain alle puolella oli ollut mahdollisuus käyttää työaikaansa uusien normien omaksumiseen, vaikka laki sosiaalihuollon ammattihenkilöistä $(817 / 2015)$ tätä edellyttää. Vain harvassa työskentelykunnassa seurattiin ja kehitettiin päihdeongelmaisten asiakkaiden hyvinvointia ja palveluita siitäkin huolimatta, että laki tätä vaatii. 
Tiedon ylläpito vaatii resursointia. Työn kehittämisen näkökulmasta tieto ja osaamisen päivittäminen asettuvat sosiaalityössä tärkeään rooliin ja seurannaisvaikutukset kohdistuvat ennen kaikkea asiakkaiden eduksi. Sosiaalityö asettuu merkittävään, eettisesti virittyneeseen rooliin. Tieto on arvokasta, kun se tuottaa käytännön hyötyjä, totesi filosofi ja valtiomies sir Francis Bacon (1561-1626). Tähän on helppo yhtyä. Sen lisäksi, että tiedon saatavuutta ja saavutettavuutta parannetaan tiedepoliittisin ratkaisuin siten kuin Januksessa on tehty eli avoimen julkaisemisen suuntaan siirtymällä, on tutkimusyhteyden säilyttämiselle luotava tilaa myös siellä, missä sosiaalityön käytännön työtä tehdään.

Kuluva vuosi on seurassa myös kasvokkaisen tutkimustiedon välittämisen vuosi; helmikuussa kuultiin ajankohtaisesta tutkimuksesta Sosiaalityön tutkimuksen päivillä Tampereen yliopistossa. Päivien yleisössä oli laajasti sosiaalityön tutkijoita, sosiaalityöntekijöitä ja muita kentän toimijoita sekä opiskelijoita. Pohjoismaisten sosiaalityön tutkimuksen seurojen (Forsa Nordic) ja sosiaalityön koulujen (NOUSA) joka toinen vuosi järjestämä Nordic Social Work Conference 2018 pidetään Helsingin yliopistossa (Svenska social- och kommunalhögskolan järjestämänä) 21.-23. marraskuuta. Konferenssin teemana on "Power and Social Work" ja se tarjoaa pohjoismaisille ja kansainvälisille tutkijoille ja sosiaalialan ammattilaisille ainutlaatuisen kohtaamispaikan ja mahdollisuuden jakaa ja luoda uutta tietoa, näkemyksiä ja kokemuksia sosiaalityön koulutuksen, tutkimuksen ja käytännön eri näkökulmista.

Nordic Social Work Conference 2018 kutsuu ja haastaa alan toimijat käsittelemään kysymyksiä vallasta, vallan puutteesta sekä valtasuhteista. Muuttuvat poliittiset intressit ja pyrkimykset sekä teknologiakehityksen luomat edellytykset herättävät uusia kysymyksï̈ valta-asetelmista ja -rakenteista sosiaalityössä. Mahdollisia kehityssuuntia pohjoismaisessa kontekstissa ovat muun muassa asiakkaiden vastuullistaminen ja tiukentuva valvonta, häilyvät institutionaaliset rajat moniammatillisten ryhmien välillä sekä sosiaalityön ammatillisuuden hämärtyminen tehtävien ja vastuun siirrolla muille toimijoille julkisen sektorin sisä- tai ulkopuolella. Yleisesti ottaen teknologian synnyttämät virtuaaliset työkalut ja sosiaalinen media tarjoavat sekä uusia mahdollisuuksia että uhkia sosiaalityölle. Kehityskulut tapahtuvat laajassa yhteiskunnallisessa kontekstissa ja ideologisesti polarisoituneessa ilmapiirissä, mikä luo epätasa-arvoa ja uusia rakenteellisia hierarkioita. Vaikutukset näkyvät kansalaisten keskuudessa, mukaan lukien kasvavassa joukossa ihmisiä,jotka ovat akuutisti sosiaalipalveluiden tarpeessa. Konferenssissa näemme myös, miten sosiaalityössä on kehittynyt uusia tapoja vaikuttaa yhteiskunnan eriarvoistaviin ja syrjiviin rakenteisiin sekä edistämään sosiaalista hyvinvointia.

Sosiaalityön tutkimuksen seuran tehtävä on osallistua tieteidenväliseen keskusteluun ja konferenssin teema avautuukin yhteiskuntatieteellisesti sosiaalityötä laajemmalle. Konferenssiin kutsutuista pääpuhujista Walter Lorenz (Bozen-Bolzanon vapaa yliopisto, Italia ja Kaarlen yliopisto, Praha) on sosiaalityön ja sosiaalipolitiikan 
eurooppalaisen vertailevan tutkimuksen keskeisimpiä nimiä. Dorte Caswell (Aalborgin yliopisto) on perehtynyt käytännön sosiaalityöhön ja -politiikkaan, erityisesti hyvinvointipolitiikan tuotoksiin asiakkaiden näkökulmasta.Virginia Eubanks (Albanyn osavaltion yliopisto, Yhdysvallat) on tutkinut ja kirjoittanut merkittäviä teoksia teknologiasta ja sosiaalisesta oikeudenmukaisuudesta sekä niiden välisistä yhteyksistä.

Yleisohjelman lisäksi Nordic Social Work Conference 2018 tarjoaa joukon temaattisia työryhmiä, joihin puheenvuorokutsu (abstraktien palautus) on auki toukokuun 21. päivään saakka. Ilmoittautuminen konferenssiin aukeaa kevään aikana:

https://www.helsinki.fi/en/conferences/nordic-social-work-conference

Sosiaalityön tutkimuksen seuran puolesta toivotan teidät lämpimästi tervetulleeksi!

\section{Katja Kuusisto}

Sosiaalityön tutkimuksen seuran pj.

Dosentti, yliopistonlehtori

Yhteiskuntatieteiden tiedekunta

Tampereen yliopisto 